\title{
Are Waterfowl Food Resources Limited during Spring Migration? A Bioenergetic Assessment of Playas in Nebraska's Rainwater Basin
}

\author{
Travis J. Schepker ${ }^{1,2}$ (D) Ted LaGrange $^{3}$ Elisabeth B. Webb ${ }^{4}$ \\ Received: 14 November 2017 / Accepted: 22 May 2018 / Published online: 5 June 2018 \\ (C) The Author(s) 2018
}

\begin{abstract}
Accurate bioenergetic carrying capacity estimates of wetlands on public and private lands, as well as those managed for crop production are important for managing waterfowl populations and habitats. Given the importance of wetlands in the Rainwater Basin region of Nebraska for spring migrating waterfowl, we quantified and compared seed and aquatic invertebrate biomass and true metabolizable energy (TME) at three wetland types; public wetlands, wetlands enrolled in the Wetlands Reserve Program (WRP), and cropped wetlands. Median seed biomass estimates at public, WRP, and cropped wetlands were $593 \mathrm{~kg} / \mathrm{ha}, 561 \mathrm{~kg} / \mathrm{ha}$, and $419 \mathrm{~kg} / \mathrm{ha}$ respectively. Cumulative TME varied among wetland type, with greater TME at cropped wetlands $(2431 \mathrm{kcal} / \mathrm{kg})$ than public $(1740 \mathrm{kcal} / \mathrm{kg})$ and WRP wetlands $(1781 \mathrm{kcal} / \mathrm{kg})$. Seed biomass estimates from this study were statistically greater than those currently used for management planning in the RWB, however, TME estimates were statistically lower than estimates currently assumed for WRP and public wetlands. Our estimates for aquatic invertebrate biomass were approximately 40-fold less than seed biomass estimates. Based on spring ponding frequency at wetlands in Nebraska's Rainwater Basin, and the caloric estimates derived for each wetland type, we concluded that the regions wetlands meet the energetic demand of spring migrating waterfowl during $10 \%$ of years.
\end{abstract}

Keywords Wetlands restoration program $\cdot$ WRP $\cdot$ Food resource availability $\cdot$ Spring migration ecology $\cdot$ True Metabolizable energy · Waterfowl · Dabbling duck · Carrying capacity · Nebraska Rainwater Basin · Annual plant seed · Perennial plant seed · Aquatic invertebrate $\cdot$ Foraging threshold

Electronic supplementary material The online version of this article (https://doi.org/10.1007/s13157-018-1047-0) contains supplementary material, which is available to authorized users.

Travis J. Schepker

Travis.J.Schepker@usace.army.mil

1 Missouri Cooperative Fish and Wildlife Research Unit, Department of Fisheries and Wildlife Sciences, University of Missouri, Columbia, MO 65211, USA

2 Present address: United States Army Corps of Engineers, 100 Arsenal Street, Saint Louis, MO 63118, USA

3 Nebraska Game and Parks Commission, 2200 N. 33rd Street, Lincoln, NE 68503, USA

4 U.S. Geological Survey, Missouri Cooperative Fish and Wildlife Research Unit, Department of Fisheries and Wildlife Sciences, University of Missouri, Columbia, MO 65211, USA

\section{Introduction}

The spring condition hypothesis acknowledges the potential relationship between food availability at migration stopover sites and subsequent reproductive success on breeding grounds (Afton and Anderson 2001; Anteau and Afton 2009). During spring, female waterfowl seek aquatic invertebrates and plant foods to accumulate the energy and protein needed to complete migration and initiate egg production (LaGrange and Dinsmore 1989; Pearse et al. 2011; Tidwell et al. 2013). When demand for quality food resources is unmet, waterfowl may arrive at nesting grounds with insufficient energy and lipid reserves, and consequently become less likely to reproduce (Heitmeyer and Fredrickson 1981; Devries et al. 2008). Given the importance of food resource acquisition at mid-latitude migration stopover sites and subsequent potential effects on migration and arrival at nesting areas, waterfowl 
managers have adopted a bioenergetics approach to guide habitat conservation planning for remaining wetlands at spring staging areas (North American Waterfowl Management Plan 2012; Straub et al. 2012; Rainwater Basin Joint Venture (RWBJV) 2013; Williams et al. 2014). This approach requires accurate estimates of: 1) habitat-specific food resource biomass (dry weight/unit area), 2) habitatspecific estimates of true metabolizable energy (TME; kcal/ dry weight), 3) habitat-specific availability (ha of foraging habitat), 4) species-specific daily energy expenditure (kcal), and 5) species-specific population goals (Williams et al. 2014). Thus the goal of this strategy is to assess a regions ability to sustain the bioenergetic demand of migratory birds. However, regional conservation planning using a bioenergetics approach is likely hindered by variation and uncertainty in daily ration model parameters, particularly the need for more accurate habitat-specific estimates of food resource biomass and corresponding TME values (Straub et al. 2012; Williams et al. 2014; Livolsi et al. 2015).

The Rainwater Basin Joint Venture (RWBJV) is responsible for developing long-term conservation strategies and delivery of wetland habitats for migratory waterfowl in Nebraska's Rainwater Basin (RWB) region. Currently the RWBJV is tasked with providing habitat, and food resources sufficient to support $\sim 10$ million spring migrants in a region that has experienced a $90 \%$ reduction in wetland area (Schildman and Hurt 1984; LaGrange 2005; Bishop and Vrtiska 2008). Reduction of quality wetland habitat can promote intense competition among birds for wetland resources during this critical period (Webb et al. 2010, Bishop et al. 2016). One strategy for providing additional wetland resources within the region involves restoring function for a portion of those wetlands previously converted to agricultural use (Bishop and Vrtiska 2008). The Natural Resources Conservation Service (NRCS) offers several voluntary conservation easement programs that provide private landowners financial and technical assistance to retire farmlands from agricultural production, and restore historic wetland hydrology (King et al. 2006). Although NRCS programs such as the Wetlands Reserve Program (WRP; enrollment expired in 2014) and Agricultural Conservation Easement Program (ACEP; established in 2014) offer financial incentives and technical support for initial habitat restoration, program participants have no contractual obligation to provide continued management to promote ecosystem function (Tapp and Webb 2015; Natural Resources Conservation Service 2017a). Cattle grazing and a variety of mechanical soil disturbance treatments are commonly used to manage wetland vegetation throughout the RWB, with the intended goal of increasing seed production by promoting early successional plant communities (LaGrange 2005; Bishop and Vrtiska 2008; RWBJV 2013). Without sporadic disturbance, annual vegetative communities may transition to dense stands of perennial monocultures, such as river bulrush (Scirpus fluviatilis) or reed canary grass (Phalaris arundinacea), that offer minimal food resources or energetic value to migratory birds (Haukos and Smith 1993; Bowyer et al. 2005; Strader and Stinson 2005; Kross et al. 2008). An alternative conservation easement strategy within ACEP is the Agricultural Land Easement option (ACEP-ALE), that involves restoring the hydrology of non-functional cropped wetlands and encouraging private landowners to continue crop production (Natural Resources Conservation Service 2017b). This strategy provides agricultural producers an additional program for floodprone cropland, where crops can be harvested during dry years, while maximizing foraging opportunities for migrating birds during years with sufficient precipitation (Nugent et al. 2015). Although conservation easement programs have become an integral tool for developing long-term wetland management strategies, their energetic contribution for waterfowl in the RWB has not been assessed.

The current bioenergetic model used for wetland conservation planning in the RWB assumes seed biomass and TME estimates derived from actively managed wetlands in Southern United States during autumn (Kaminski et al. 2003; Bishop and Vrtiska 2008). There is likely a spatial bias associated with these estimates as vegetative communities and seed production can vary across regions resulting from length of growing season at different latitudes (Olmstead et al. 2013; Tapp et al. 2017), annual precipitation (Casanova and Brock 2000), soil type (Reed 1988), and interactions with exotic or endemic species (Houlahan and Findlay 2004). In addition, seed biomass estimates developed during autumn would likely overestimate actual seed availability during spring, resulting depletion by autumn migrants and decomposition (Greer et al. 2007; Brasher et al. 2007; Hagy and Kaminski 2012; Williams et al. 2014). Brasher et al. (2007) acknowledged an $80 \%$ decrease in food resource availability between autumn and spring migration at actively and passively managed wetlands in Ohio, suggesting spring is the most foodlimited season for non-breeding waterfowl. Drahota and Reichart (2015) assessed seed biomass at the most productive public wetlands in the RWB, and reported seed biomass as much as four times greater than current estimates used for spring conservation planning in the RWB. Although these estimates are useful for assessing seed biomass in actively managed public wetlands, they may not represent seed biomass at conservation easements and cropped wetlands, which account for greater than $30 \%$ of ponded wetland area in the RWB during years with average precipitation (RWBJV 2013).

Energetic contributions recognized by the RWBJV for developing bioenergetics models focus exclusively on seed biomass estimates (Bishop and Vrtiska 2008; Nugent et al. 2015). While plant seeds are consistently the primary wetland food resource consumed by most dabbling ducks during spring migration, aquatic invertebrates are likely also an essential 
food resource given their high protein content and the shift in waterfowl diets to contain a greater proportion of invertebrates during spring (Anderson and Smith 1998; Hitchcock 2008; Pearse et al. 2011; Tidwell et al. 2013). Although the exact phenology of shift in dabbling duck diets from high-calorie to high-protein food sources is unclear, and is likely influenced by a number of factors (e.g., food availability, use of exogenous nutrients in egg formation, annual weather), the shift is thought to be a requirement for optimal reproduction to occur (Swanson et al. 1985; Euliss and Harris 1987; Ankney and Alisauskas 1991).

Waterfowl food resources are potentially limited during spring migration (Brasher et al. 2007; Straub et al. 2012) and given the reduction in wetland habitat in the RWB, it is critical to determine the region's bioenergetic carrying capacity for spring migrating dabbling ducks. Therefore, we conducted a regional study to: 1) estimate plant seed biomass and associated TME at public, conservation easement, and cropped wetlands, 2) estimate the potential energetic contribution of aquatic invertebrates to water birds, and 3) conduct an energetic assessment to evaluate the potential spring caloric value of wetland habitats in the RWB to determine if the energetic demands of migrating waterfowl are being met.

\section{Methods}

\section{Wetland Selection}

Our study was conducted in the RWB of Nebraska from 18 February - 24 April, 2014 and 11 February - 13 April, 2015. The RWB spans 21 counties in south-central Nebraska, adjacent to the southern border of the Platte River (Fig. 1). Most wetlands within the region are classified as playas, which are small depressional wetlands, lined with a clay layer with low permeability and located at the low spot of closed basin watersheds (Smith 2003). Playas in the RWB are seasonally or ephemerally inundated, with historic hydrologic processes driven by surface runoff following precipitation events and accumulated snowmelt (Bolen et al. 1989; Cariveau et al. 2011). Historically, the RWB included $>11,000$ playas that would have provided approximately 80,000 ha of wetland habitat (Bishop and Vrtiska 2008). However, drainage ditches, irrigation pits, culturally-accelerated sedimentation, and agricultural expansion resulted in a long-term decline of up to $90 \%$ of wetland area within the region (Raines et al. 1990; Bishop and Vrtiska 2008). Wetland loss in the RWB is magnified during drought years, when a large portion of the remaining wetlands fail to pond water. Ground water pumping is available for some public wetlands to offset drought conditions, however the high cost associated with installation and maintenance of pumping infrastructure leaves most private wetlands without such capabilities (personal communication with landowners).

Study sites were located on public lands managed by the Nebraska Game and Parks Commission and the U.S. Fish and Wildlife Service, on private conservation easement lands enrolled in the WRP, and on private lands managed for agricultural crop production. The WRP expired in 2014, and has since been replaced by the ACEP. All conservation easements included in this study were enrolled under WRP, thus we refer to all conservation easements as such hereafter. Private lands managed for crop production pond water following intense precipitation events in areas where functional playa wetlands historically occurred (Personal communication, J. Drahota, USFWS). Although native moist-soil wetland plant communities are not management objectives at cropped fields, low densities of dormant seeds in remnant seed banks can germinate and mature given appropriate conditions (i.e. moist-soil). Albeit highly modified, hereafter we hereafter refer to privately owned, ephemeral wetlands managed for crop production as cropped wetlands.

Study sites were limited by minimal precipitation leading into and during springs 2014 and 2015. We stratified potential study sites by county, identified the six counties containing the greatest number of public wetlands that ponded water (Nebraska Game and Park Spring Habitat Conditions Summary 2014 and 2015) and randomly selected public wetlands within these counties (Stafford et al. 2006; Tapp et al. 2017). Inclusion of WRP and cropped wetlands was conditional based on proximity to public wetlands, inundation frequency, and landowner participation. In 2014, we selected 12 public, $10 \mathrm{WRP}$, and 10 cropped wetlands. In 2015 we selected 12 public, 11 WRP, and 10 cropped wetlands. In February 2014 all public wetlands ponded water; however only three WRP, and three cropped wetlands ponded water. In February 2015 all public and WRP wetlands ponded water, however no cropped wetlands ponded water. During both years we sampled 18 public, 17 WRP, and 13 cropped wetlands, thus some, but not all wetlands were sampled during both years. We acknowledge that assessing foraging conditions at private sites not ponding water was not ideal, however minimal precipitation leading into springs 2014 and 2015 provided limited alternatives. Regardless, all WRP sites exhibited some levels of ponding during the previous two years and all cropped wetlands had been inundated during the previous five years (personal communication with landowners and annual inundation surveys provided by the RWBJV). Cattle grazing and mowing were the primary management strategies used at public and WRP wetlands. All public and $81 \%$ of WRP wetlands had received some level of management during the previous three years (personal communication with private and public land managers). Maize (Zea spp.), sorghum (Sorghum bicolor), and soybeans (Glycine max) were the only crops observed at cropped wetlands. 
Fig. 1 Locations of study sites within the Nebraska Rainwater Basin, USA where food resources were estimated during spring 2014-2015

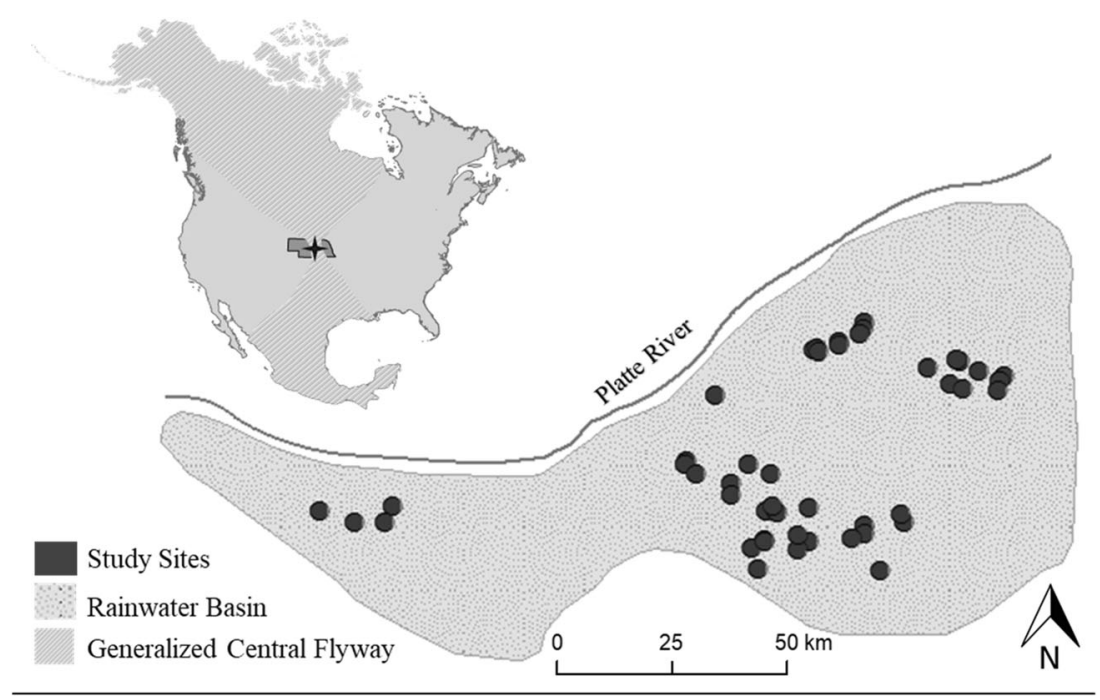

\section{Quantification of Plant Seed Biomass and Caloric Value for Waterfowl}

We collected plant seed biomass, consisting of moist-soil seeds and waste grains, during two sampling events each spring. Initial seed samples were collected at all sites prior to arrival of most spring migrating waterfowl (mid-February through the first week of March), regardless of inundation status, and a second time when we considered the majority of spring migrants had departed the region (last two weeks of April; Drahota and Reichart 2015). We collected 10-20 soil cores (dependent on wetland area) during each sampling event at random locations along a transect positioned across the widest portion of each wetland (Greer et al. 2007; Olmstead et al. 2013; Behney et al. 2014). For sites not ponding water at the time of seed collection, we used aerial imagery from previous years of above average precipitation to identify areas where ponding frequently occurred and established sampling transects accordingly. Soil core samples measured $10 \mathrm{~cm}$ in diameter $\left(78.54 \mathrm{~cm}^{2}\right)$ and we removed from the top $5 \mathrm{~cm}$ of substrate (Evans-Peters et al. 2012; Olmstead et al. 2013).

Soil cores were deflocculated in a hydrogen peroxide and baking soda solution to separate fine clay sediments (Hagy and Kaminski 2012). We rinsed soil samples through a series of two graduated sieves $(\# 10[250 \mu \mathrm{m}]$, and \#50 [500 $\mu \mathrm{m}])$ to remove small clay particles, and isolate remaining materials into coarse and fine samples (Greer et al. 2007). Samples were dried to constant dry-mass at $60{ }^{\circ} \mathrm{C}$ for $48 \mathrm{~h}$ in a convection oven and weighed to the nearest $0.1 \mathrm{mg}$. Seeds were removed from the coarse and fine debris samples, identified to genus, weighed to the nearest $0.1 \mathrm{mg}$, and converted to biomass estimates (kg/ha; Kross et al. 2008, Straub et al. 2012). Previous studies have suggested that $\sim 16 \%$ of seed biomass is lost during processing (destroyed during sieving or not identified while sorting), thus we corrected for potential seed loss in this study by multiplying all raw biomass measurements by 1.16 (Hagy et al. 2011; Drahota and Reichart 2015). We determined available energy $(\mathrm{kcal} / \mathrm{ha})$ by multiplying mean biomass of an individual seed taxa by the corresponding published value of true metabolizable energy (gross energy in kilocalories of food consumed minus the gross energy of excreta; Schepker 2017; Appendix A). We were unable to identify TME values for Marsilea spp. sporocarps, a genus from the family Marsileaceae, thus we used methods described by Straub (2008) to estimate TME based on crude fiber estimates observed in collected Marsilea sporocarps. Finally, we estimated cumulative TME across all plant genera present at a wetland by summing the products of genus biomass (percentage of total biomass for all genera) and the corresponding TME value, and dividing by the sum of weights (Williams et al. 2014);

$\bar{x}=\frac{\sum_{i=1}^{n} w_{i}{ }^{*} x_{i}}{\sum_{i=1}^{n} w_{i}}$

where,

$\bar{x}$ The weighted average of TME $(\mathrm{kcal} / \mathrm{kg})$ across all genera present at a single wetland

$w_{i} \quad$ The weight or percentage of a genus seed biomass contributed to the overall seed biomass of all genera

$x_{i} \quad$ The TME value of an individual species/genus

\section{Quantification of Aquatic Invertebrates Biomass and Caloric Value}

We assessed aquatic invertebrate biomass in alternating weeks at 17 wetlands in 2014 and 24 wetlands in 2015. At each wetland, we established 3-5 (dependent on wetland area) randomly located $3 \mathrm{~m} \times 3 \mathrm{~m}$ sample plots at water depths $<30 \mathrm{~cm}$ (preferred range of foraging depths for dabbling ducks; 
Fredrickson 1991) and where vegetative cover was $<50 \%$. Within each plot, we collected two nektonic samples using a $500 \mu \mathrm{m}$ rectangular sweep net (Murkin et al. 1994; Tapp and Webb 2015). The net was lowered vertically into the water column, pressed firmly against the substrate, and bounced through the water column for a distance of $1.1 \mathrm{~m}\left(0.5 \mathrm{~m}^{2}\right.$; Klemm et al. 1990; Davis and Bidwell 2008). We also collected two benthic samples using a 10 - $\mathrm{cm}$ diameter $\times 5$-cm deep benthic core sampler in an undisturbed area adjacent to the corresponding nektonic sampling location (Swanson 1983). Benthic and nektonic samples were preserved in $70 \%$ ethanol to prevent deterioration (Murkin and Kadlec 1986a) and shipped to the University of Missouri for processing.

To increase efficiency for invertebrate sorting and identification, we stained samples with rose bengal for $24 \mathrm{~h}$ prior to sorting (Sherfy et al. 2000; Tapp and Webb 2015). We rinsed invertebrate samples through a series of two graduated sieves (\#50 [500 $\mu \mathrm{m}]$ and \#10[250 $\mu \mathrm{m}]$ ) to remove small clay particles and partition remaining materials into coarse and fine samples (Tapp and Webb 2015). We used a Folsom wheel sample splitter (Aquatic Research Instruments) to subsample (1/4 volumes) material retained by the $250 \mu \mathrm{m}$ and $500 \mu \mathrm{m}$ sieve (Meyer et al. 2011; Whiting et al. 2011; Tapp and Webb 2015). Aquatic invertebrates were removed from remaining debris, adults and larvae were identified to the lowest taxonomic level practical, measured to the nearest millimeter, and catalogued (Kaminski and Prince 1981; Straub et al. 2012). Biomass estimates for individual taxa were obtained using published dry length-mass regressions (Duffy and LaBar 1994; Benke et al. 1999). When a length-mass regression was not available for specific taxa, we used estimates from similar species observed in comparable habitats (Benke and Huryn 2006). We were unable to identify published lengthmass regression models for taxon similar to phylum Nematoda and class Hirudinea. Further, we were unable to obtain published length-mass regression models for taxa within the order Gastropoda that did not include shell mass. Using a subset of specimens collected from our study, we developed dry length-mass regressions for Nematoda and Hirudinea, and length-mass regressions that excluded the shells of families Planorbidae, Physidae, and Bithyniidae following methods by Benke et al. 1999 (Supplementary Material A). Biomass estimates were pooled and averaged for all taxa collected at a wetland for each sampling event and converted to biomass estimates ( $\mathrm{kg} / \mathrm{ha})$. We determined available energy ( $\mathrm{kcal} / \mathrm{ha})$ by multiplying the mean biomass of all invertebrate taxa by a factor of $580 \mathrm{kcal} / \mathrm{kg}$ (Hohman et al. 1988; Straub et al. 2012).

\section{Statistical Analysis}

During both years, seed biomass values were not normally distributed and contained outliers that we believed to be ecologically relevant for our analysis. Thus, we applied the wilcox.test function in program R (Wilcoxon 1945; R Development Core Team 2017) to compare paired samples when evaluating seed depletion. We also applied the onetailed wilcox.test function in Program R (Wilcoxon 1945; R Development Core Team 2017) to test whether seed biomass exceeded a foraging threshold of $200 \mathrm{~kg} / \mathrm{ha}$. Foraging thresholds can occur when biomass falls below a level at which time the energetic cost of foraging exceeds the energetic benefit (Reinecke et al. 1989; Hagy and Kaminski 2015; Williams et al. 2014). Although there has been debate as to what an appropriate foraging threshold should be for dabbling ducks foraging on moist-soil seeds, $200 \mathrm{~kg} / \mathrm{ha}$ is regarded as a relatively conservative threshold (Williams et al. 2014; Hagy et al. 2017).

We compared plant seed biomass, TME, and energy produced for each wetland type using measures of central tendency (e.g., median), as each metric followed a non-normal distribution, and there is considerable uncertainty whether spring-migrating waterfowl distribute themselves in an ideal free manner relative to energy available in wetlands (Straub et al. 2012). We used a non-parametric Kruskal-Wallis H test in program R (R Development Core Team 2017) to test for differences in seed biomass, TME, and energy among wetland types (Kruskal and Wallis 1952). Proceeding each KruskalWallis $\mathrm{H}$ test, we tested data for general Kruskal-Wallis $\mathrm{H}$ test assumptions including homogeneity of distributions. Raw distributions were not homologous (Levene 1960; Fox et al. 2016) and were thus $\log$ transformed. Following a statistically significant result, we conducted Dunn's multiple comparison test to assess differences between independent wetland types (Dinno 2015).

Total area (based on hydrologic footprint) for public, WRP, and cropped wetlands was approximately $11,582 \mathrm{ha}, 2117 \mathrm{ha}$, and 65,874 ha respectively (Bishop et al. 2016). However actual wetland area available to waterfowl is dependent upon a hydrologic footprint ponding water. We corrected for actual wetland area available for duck use by multiplying potential wetland area by an annual spring inundation frequency factor specific to each wetland type (refer to Bishop et al. 2016 for methods used to determine annual spring inundation frequency). To determine the overall caloric contribution of each wetland type, we multiplied ponded wetland area by the corresponding bioenergetic estimate $(\mathrm{kcal} / \mathrm{ha})$. Finally, total energetic carrying capacity for spring migrating waterfowl was estimated by summing available energy for each wetland type (Supplementary Materials B).

\section{Results}

\section{Plant Seed Composition}

We collected and processed 1202 soil core samples from 24 public, $21 \mathrm{WRP}$, and 20 cropped wetlands during springs 
2014 and 2015. We identified seeds from 42 native, exotic, and agricultural plant genera. Polygonum spp., Echinochloa spp., Sparganium spp., Potamogeton spp., and Scirpus spp. were the most common native plant genera observed, and accounted for $73 \%$ of the total native seed biomass in both years (Schepker 2017). Glycine spp. and Zea spp. were the most common agriculture plant genera observed and accounted for $97 \%$ of the total agricultural seed biomass observed in both years (Schepker 2017). Our Wilcoxon Ranks Test indicated that pre and post-migration seed biomass estimates were not statistically different in $2014(\mathrm{Z}=94, p=0.42)$ or $2015(\mathrm{Z}=207, p=0.24)$, indicating minimal seed depletion.

Seed biomass estimates $(\mathrm{kg} / \mathrm{ha})$ did not differ among wetland type in $2014\left(\mathrm{H}_{2,30,0.05}=5.76\right.$; Table 1). Among wetlands sampled in 2014, median seed biomass was significantly greater than $200 \mathrm{~kg} / \mathrm{ha}$ at public $(Z=74, p=0.002)$ and WRP wetlands $(Z=52, p=0.005)$, but did not exceed the $200 \mathrm{~kg} / \mathrm{ha}$ threshold in cropped wetlands $(Z=41, p=0.097)$. Wetland-specific estimates of mean seed biomass in 2014 were greater than the $200 \mathrm{~kg} /$ ha threshold at $83 \%$ of public sites, $90 \%$ of WRP sites, and $70 \%$ of cropped sites (Fig. 2). Mean ranks of TME $(\mathrm{kcal} / \mathrm{kg})$ for seeds collected in 2014 varied among wetland type $\left(\mathrm{H}_{2,30,0.05}=7.38\right)$. Overall TME was greater in cropped fields (median $=2405 \mathrm{kcal} / \mathrm{kg}$ ) than public wetlands (median $\left.=1750 \mathrm{kcal} / \mathrm{kg}: \mathrm{Z}_{21,0.05}=2.64\right)$, but TME did not differ among other pairwise comparisons $(p>$ 0.05 ; Fig. 3). Energy produced by seeds collected in 2014 did not vary among wetland type $\left(\mathrm{H}_{2,30,0.05}=2.68\right)$.

Seed biomass estimates did not differ among wetland types in $2015\left(\mathrm{H}_{2,31,0.05}=1.60\right.$ (Table 1). Wetland-specific estimates of mean seed biomass in 2015 were greater than the $200 \mathrm{~kg} / \mathrm{ha}$ threshold at $100 \%$ of public sites, $90 \%$ cropped sites, and $91 \%$ WRP sites (Fig. 2). Overall, median seed biomass exceeded the $200 \mathrm{~kg} / \mathrm{ha}$ threshold at all wetland types $(p<0.05)$. Mean ranks of TME for seeds collected in 2015 varied among wetland types $\left(\mathrm{H}_{2,31,0.05}=11.83\right)$. Overall TME was greater in cropped fields $($ median $=2587 \mathrm{kcal} / \mathrm{kg})$ than public $($ median $=$ $1714 \mathrm{kcal} / \mathrm{kg}: Z_{21,0.05}=3.23$ ) and WRP wetlands (median = $1804 \mathrm{kcal} / \mathrm{kg}: Z_{20,0.05}=2.73$ ), however TME did not differ between WRP and public wetlands $\left(Z_{22,0.05}=0.46\right.$; Fig. 3$)$. Energy produced by seeds collected in 2015 did not vary among wetland types $\left(\mathrm{H}_{2,31,0.05}=2.80\right)$.

\section{Macroinvertebrate Composition}

We collected and processed 1524 invertebrate samples from 41 wetlands during springs 2014 and 2015. Given the limited number of ponded WRP and cropped wetlands, we combined data from both years and all wetland types when summarizing aquatic invertebrates. Forty-five invertebrate families were identified from nektonic and benthic communities (Schepker 2017). Among the most frequently observed taxonomic orders during both years were Diptera, Gastropoda, Odonata, Copepoda, and Anostraca. During both years, invertebrate biomass $(\mathrm{kg} / \mathrm{ha}$ ) was greater in benthic communities, however taxonomic richness was greater in nektonic communities. Mean aquatic invertebrate biomass observed in benthic samples during 2014 and 2015 was $8.45 \mathrm{~kg} / \mathrm{ha}(\mathrm{SE}=1.62)$, and $9.88 \mathrm{~kg} / \mathrm{ha}(\mathrm{SE}=1.79)$ respectively (Table 2$)$. Mean aquatic invertebrate biomass observed in nektonic samples was $1.81 \mathrm{~kg} / \mathrm{ha}(\mathrm{SE}=0.55)$, and $6.29 \mathrm{~kg} / \mathrm{ha}(\mathrm{SE}=0.84)$ during 2014 and 2015, respectively. Plant seed biomass estimates exceeded aquatic invertebrate biomass at all sites $(n=41)$ in 2014 and 2015. We estimated the caloric value of aquatic invertebrates at playa wetlands in the RWB as $7958 \mathrm{kcal} / \mathrm{ha}$.

From 2006 to 2015, we estimated annual mean energy at ponded wetlands in the RWB to be 1.2 billion kcal (Supplementary Material B). During the 10-year period, estimated mean annual energy produced varied among wetland types $\left(\mathrm{F}_{2,27,0.05}=3.35\right)$. Ponded area was greatest for public wetlands, and consequently public wetlands represented the greatest caloric contribution to energetic carrying capacity in the RWB. Although ponded area was greater at cropped

Table 1 Estimates of median, mean, standard error (SE), and 95\% confidence intervals (CI) for seed biomass (kg/ha dry mass), TME (kcal/kg), and Energy (kcal/ha) collected in public, Wetlands Reserve Program WRP) and cropped wetlands during springs 2014 and 2015

\begin{tabular}{|c|c|c|c|c|c|c|c|c|c|c|}
\hline \multirow[b]{2}{*}{ Year } & \multirow[b]{2}{*}{ Metric } & \multicolumn{3}{|c|}{ Public Wetlands } & \multicolumn{3}{|c|}{ WRP Wetlands } & \multicolumn{3}{|c|}{ Cropped Wetlands } \\
\hline & & Biomass & TME & Energy & Biomass & TME & Energy & Biomass & TME & Energy \\
\hline \multirow[t]{4}{*}{2014} & Median & 582 & 1750 & 768,020 & 569 & 1776 & $1,112,588$ & 310 & 2405 & 632,648 \\
\hline & Mean & 546 & 1652 & 898,015 & 594 & 1832 & $1,013,186$ & 281 & 2256 & 613,029 \\
\hline & SE & 104 & 78 & 191,492 & 133 & 112 & 183,466 & 55 & 137 & 127,309 \\
\hline & $\mathrm{CI}$ & 229 & 172 & 421,471 & 300 & 253 & 415,028 & 125 & 311 & 287,992 \\
\hline \multirow[t]{4}{*}{2015} & Median & 651 & 1714 & 892,954 & 560 & 1804 & $1,090,553$ & 637 & 2587 & $1,413,891$ \\
\hline & Mean & 695 & 1665 & $1,192,197$ & 540 & 1741 & 964,815 & 934 & 2511 & $2,448,435$ \\
\hline & SE & 93 & 97 & 226,274 & 91 & 86 & 195,223 & 243 & 207 & 727,825 \\
\hline & CI & 204 & 213 & 498,024 & 203 & 192 & 434,983 & 550 & 469 & $1,646,454$ \\
\hline
\end{tabular}




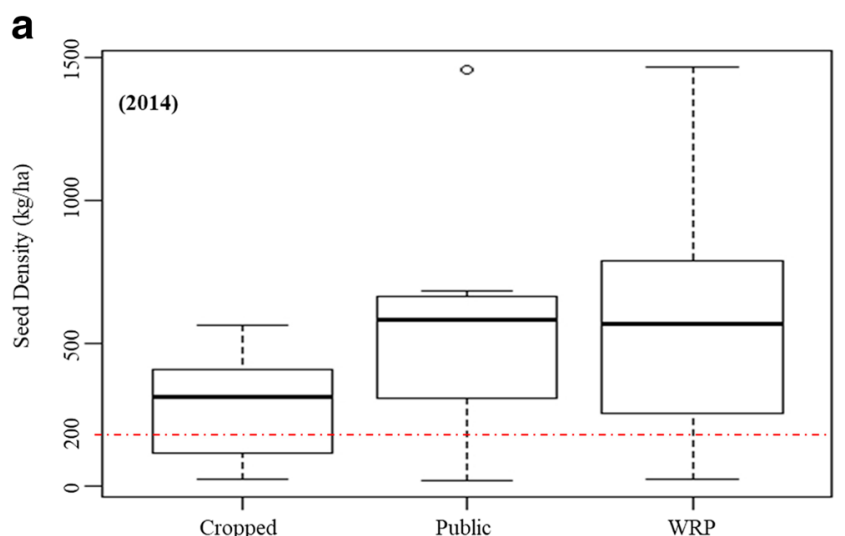

b



Fig. 2 Seed biomass at cropped, public, and Wetlands Reserve Program (WRP) wetlands during springs 2014 (a) and 2015 (b). The horizontal line $(200 \mathrm{~kg} / \mathrm{ha})$ represents a foraging threshold which recognizes the point at which a wetland would have little to no forage value to dabbling ducks. The foraging threshold was exceeded at $70 \%$ of cropped, $83 \%$ of public, and $90 \%$ of WRP wetlands sampled in 2014 and $90 \%$ of cropped, $100 \%$ of public, and $91 \%$ of WRP wetlands sampled in 2015

wetlands than WRP wetlands, there was no difference in available caloric production between the two wetland types $\left(t_{18,0.05}=0.08\right)$. Based on these projections and estimates, the RWBJVs annual objective for providing 4.4 billion kilocalories to spring migratory waterfowl was achieved in one year over the 10-year period of assessment.

\section{Discussion}

Food resources for migrating waterfowl are often considered limited during spring migration, as a result of seed depletion by fall migrants and decomposition (Nelms and Twedt 1996; Greer et al. 2007; Barney 2008; Foster et al. 2010). Nevertheless, our estimates for spring biomass were similar to estimates reported by studies conducted prior to, or during autumn migration (Kross et al. 2008; Evans-Peters et al. 2012; Olmstead et al. 2013). Over $90 \%$ of the public and WRP wetlands included in this study had seed biomass exceeding $200 \mathrm{~kg} / \mathrm{ha}$, suggesting that the vast majority of wetlands in the a

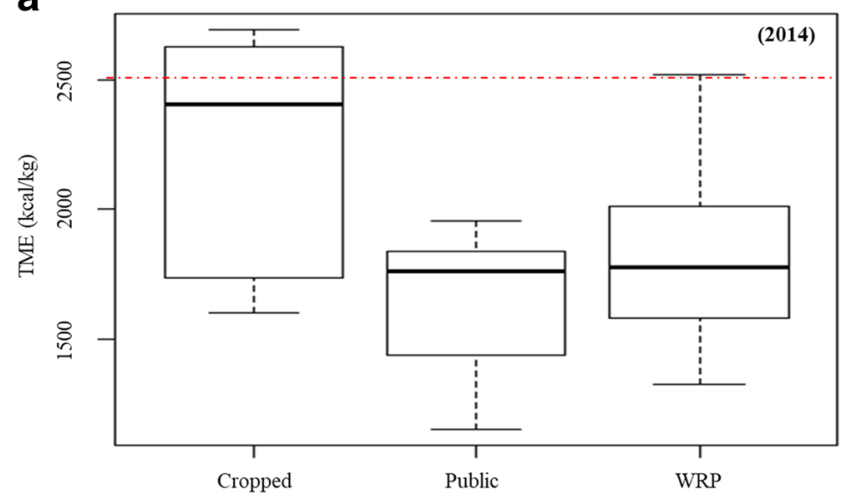

b

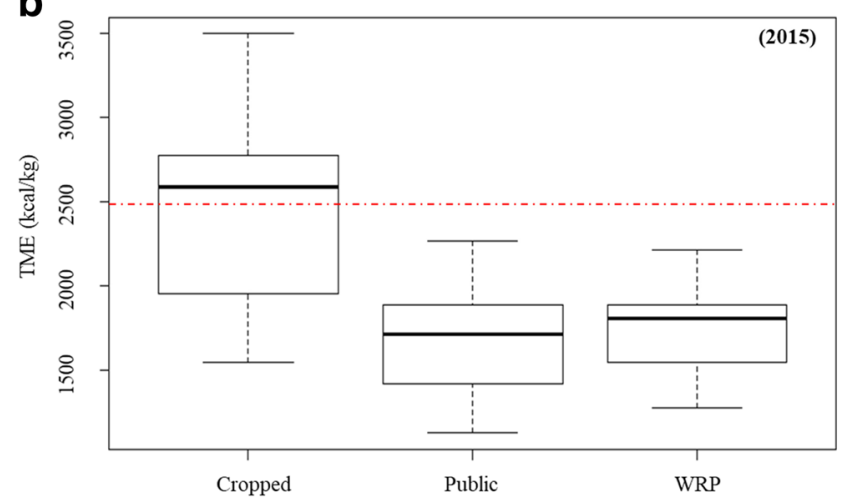

Fig. 3 True Metabolizable Energy (TME) at cropped, public, and Wetlands Reserve Program (WRP) wetlands during springs 2014 (a) and 2015 (b). The horizontal line at $2470 \mathrm{kcal} / \mathrm{kg}$ represents a TME estimate commonly when constructing bioenergetic models throughout North America. TME values observed at public and WRP wetlands were significantly less than $2470 \mathrm{kcal} / \mathrm{kg}$ in the Rainwater Basin

RWB offer beneficial spring foraging opportunities. Although seed biomass at wetlands in the RWB appears to be sufficient at the local level, concerns are likely warranted when assessing seed availability at the regional level. Specifically, during dry years when seed biomass at wetlands is substantial, however only a small percentage of those wetlands is available to foraging dabbling ducks resulting from minimal precipitation.

The Wetlands Reserve Program appears to be a viable conservation strategy for increasing suitable waterfowl foraging habitat in the RWB. Our estimate for seed biomass at WRP sites was $566 \mathrm{~kg} / \mathrm{ha}$, which was similar to seed estimates for public wetlands ( $621 \mathrm{~kg} / \mathrm{ha}$ ). In addition to quantity, the nutritional quality of seeds, in terms of TME, was also comparable between the two wetland types. Although incidental, active management techniques used among the two wetland types may explain comparable plant communities (Olmstead et al. 2013; Tapp et al. 2017). Vegetative disturbance techniques such as prescribed burning, disking, and mowing are commonly associated with moist-soil management, with the objective of maintaining plant communities in earlysuccessional stages (Fredrickson and Taylor 1982). The cost and labor required to implement these disturbance techniques 
Table 2 Estimates of mean, standard error (SE), median, and $95 \%$ confidence intervals $(\mathrm{CI})$ for invertebrate biomass $(\mathrm{kg} / \mathrm{ha}$ dry mass) at wetlands in Nebraska's Rainwater Basin during springs $2014(\mathrm{n}=17)$ and $2015(\mathrm{n}=24)$

\begin{tabular}{|c|c|c|c|c|c|c|}
\hline \multirow[b]{2}{*}{ Metric } & \multicolumn{2}{|c|}{2014 Invertebrate Biomass } & \multicolumn{2}{|c|}{2015 Invertebrate Biomass } & \multicolumn{2}{|c|}{ Average Biomass } \\
\hline & Benthic & Nektonic & Benthic & Nektonic & Benthic & Nektonic \\
\hline Mean & 8.45 & 1.81 & 9.88 & 6.29 & 9.29 & 4.43 \\
\hline SE & 1.62 & 0.55 & 1.79 & 0.84 & 1.24 & 0.64 \\
\hline Median & 6.80 & 0.93 & 6.42 & 5.04 & 6.66 & 3.58 \\
\hline Lower CI & 5.02 & 0.63 & 6.18 & 4.54 & 6.79 & 3.13 \\
\hline Upper CI & 11.88 & 2.98 & 13.59 & 8.03 & 11.79 & 5.73 \\
\hline
\end{tabular}

are a concern for landowners with no perpetual obligation to manage waterfowl foraging habitats on WRP easements (King et al. 2006; Tapp and Webb 2015). Consecutive years of passive or no management can promote dense stands of late-successional plant species that often produce fewer seeds and are associated with less desirable TME values (Fredrickson and Taylor 1982; Olmstead et al. 2013). Conversely, WRP enrollees in the RWB also have the option of cattle grazing during certain months of the year, which mimics a natural vegetative disturbance (Stutheit et al. 2004; LaGrange 2005; Marty 2005). Among the private landowners who permitted us access to their WRP wetlands, approximately $80 \%$ used cattle grazing as an indirect management tool to control persistent emergent vegetation and promote early successional plant communities.

Although less common and still in initial implementation phase, the Agricultural Land Easement (ALE) option within the Agricultural Conservation Easement Program could serve as an alternative to, or, complement the WRP (Nugent et al. 2015). Although we did not collect samples from ALEs, seed biomass estimates derived from cropped wetlands are likely equivalent and may offer some guidance when assessing the program's potential for meeting waterfowl foraging habitat goals. Site-specific seed biomass at cropped wetlands were highly variable, ranging from 23 to $2680 \mathrm{~kg} / \mathrm{ha}$ over both years (Fig. 2), and the majority of this variation was explained by harvest during the preceding autumn. Over both years, mean seed biomass at harvested sites $(n=15)$ was $480 \mathrm{~kg} /$ ha, compared to $991 \mathrm{~kg} / \mathrm{ha}$ at sites $(n=5)$ that went unharvested during the preceding fall (Table 3 ). In addition to biomass, the caloric value of waste grains commonly produced in the RWB (Zea mays and Glycine max) are estimated to be twice that of annual smartweed (Polygonum spp.), which was the most frequently observed native seed in this study (Reinecke et al. 1989; Ballard et al. 2004). Despite the caloric benefit waste grains offer, they can fail to provide dabbling ducks with the range of nutrients necessary to complete life history requirements and maintain optimal body condition (Baldassarre et al. 1983; Loesch and Kaminski 1989; Miller et al. 2000). Still, estimated median biomass for native moistsoil seeds at cropped wetlands was $333 \mathrm{~kg} / \mathrm{ha}$, which is above the proposed foraging threshold of $200 \mathrm{~kg} / \mathrm{ha}$, indicating that cropped fields ponding water have potential to provide waterfowl with meaningful energetic foraging opportunities from both waste grains and/or recruitment moist-soil seeds.

Mean TME provided by a gram of seed across all moist-soil plant species is generally estimated as $2470 \mathrm{kcal} / \mathrm{kg}$ (Kaminski et al. 2003; Bowyer et al. 2005; Kross et al. 2008; RWBJV 2013); however, variation in seed composition resulting from differences in plant community, vegetative manipulations, and geographic location may influence exact estimates (Dugger et al. 2007; Williams et al. 2014). For instance, a late-successional stand dominated by bulrush (Scirpus spp.) and spike rush (Eleocharis spp.) would likely have an overall TME less than $1000 \mathrm{kcal} / \mathrm{kg}$, whereas an early-successional stand of smartweed (Polygonum spp.) and barnyard grass (Echinochloa spp.) would be associated with an overall TME of $2000 \mathrm{kcal} / \mathrm{kg}$ (Sherfy 1999; Ballard et al. 2004; Dugger et al. 2007; Straub 2008). Further, TME may exceed $3000 \mathrm{kcal} / \mathrm{kg}$ when assessing agricultural waste grains in cropped wetlands (Reinecke et al. 1989). For public and WRP wetlands assessed in this study, we estimated TME to be significantly less than the $2470 \mathrm{kcal} / \mathrm{kg}$ used as an average in other studies (Bowyer et al. 2005; Kross et al. 2008). Thus, continuing to use $2470 \mathrm{kcal} / \mathrm{g}$ when modeling energetics in the RWB, or other regions where the plant community has not been assessed, will likely substantially overestimate actual accessible energy to waterfowl when all other metrics (seed biomass and ponded area) remain

Table 3 Seed composition observed at cropped wetlands where row crops were not harvested during the previous fall $(n=5)$

\begin{tabular}{|c|c|c|c|c|c|c|}
\hline & \multicolumn{3}{|c|}{ Agricultural Waste Grains } & \multicolumn{3}{|c|}{ Moist-Soil Seeds } \\
\hline & Biomass & TME & Energy & Biomass & TME & Energy \\
\hline Mean & 653 & 3058 & $1,996,874$ & 339 & 2045 & 693,255 \\
\hline Median & 497 & 2650 & $1,317,050$ & 340 & 2422 & 823,480 \\
\hline SE & 230 & 559 & 128,570 & 22 & 313 & 6886 \\
\hline Upper CI & 1291 & 3751 & $4,843,547$ & 399 & 2914 & $1,162,686$ \\
\hline Lower CI & 15 & 2365 & 34,841 & 279 & 1176 & 328,104 \\
\hline
\end{tabular}

Crops went unharvested when land managers were unable to operate equipment in the wet soils. Estimates of mean, standard error (SE), median, and $95 \%$ confidence intervals $(\mathrm{CI})$ for seed biomass $(\mathrm{kg} / \mathrm{ha}$ dry mass), TME (kcal/kg), and energy (kcal/ha) 
constant. Based on our findings, future seed biomass assessments may also consider accounting for species composition of plant seeds collected, as associated TME values can reduce uncertainty and variation a when constructing effective bioenergetic models for a region (Livolsi et al. 2015).

The relatively low abundance and patchy distributions of aquatic invertebrates during spring migration likely presents a challenge for waterfowl biologists to identify appropriate target aquatic invertebrates biomass (Murkin and Kadlec 1986a; Drahota and Reichart 2015; Stafford et al. 2016). Our study estimates of mean aquatic invertebrate biomass were approximately 40 -fold less than estimates for mean seed biomass. Davis and Bidwell (2008) observed similar densities of aquatic invertebrates during spring in the RWB, however our estimates were considerably lower than those reported by studies outside the RWB (Hohman et al. 1988; Johnson 2007; Straub et al. 2012). In an effort to evaluate the role of invertebrates in influencing waterfowl habitat use, Schepker (2017) explained dabbling duck densities in the RWB using several metrics of food resource availability and reported a significant relationship between dabbling duck density and seed biomass, however no relationship was observed between dabbling duck density and aquatic invertebrate biomass. Tapp (2013) observed similar results when assessing dabbling duck abundance in the Lower Mississippi Alluvial Valley during autumn and winter, although Murkin and Kadlec (1986b) observed a strong positive relationship between dabbling duck density and invertebrate biomass during late spring/early summer on Manitoba breeding grounds. Despite lack of consistent evidence that invertebrate biomass influence dabbling duck habitat use during the non-breeding season, diet studies have emphasized the importance of invertebrates during spring migration (Hitchcock 2008; Tidwell et al. 2013). Given that invertebrate biomass is generally not incorporated into energetic carrying capacity models, there is rarely a standardized or well defined target for invertebrate abundance or biomass, which would likely vary across space and time.

\section{Management Implications}

Our bioenergetics assessment indicated that available energy for spring-migrating waterfowl in wetlands exceeded the RWBJVs energetic objective of 4.4 billion kilocalories in only one year from 2006 to 2015 (Supplementary Material B). Based on our observations at seasonally flooded wetlands in the RWB, seed biomass appears sufficient to achieve this energetic objective on a more consistent basis, provided sufficient wetlands are inundated to make these food resources available to dabbling ducks. Although TME was far below expectations in moist-soil units, its potential to increase in the RWB is improbable considering most wetlands already receive management for early-successional plant communities. Increasing ponded area of unharvested cropped fields would likely be the most efficient method for increasing available energy during spring; however, the utility of this approach may not benefit all wetland-dependent wildlife (Gray et al. 2004; Riens et al. 2013; Casanova and Casanova 2016). Although beyond the scope of this study, developing methods to increase inundation frequency during years with minimal precipitation would likely increase accessible food resources for waterfowl. Despite the potential for WRP sites to provide waterfowl with optimal foraging opportunities, only 3 and 5\% of WRP wetland area ponded water in 2014 and 2015 (Bishop et al. 2016). Fully restoring wetland hydrology and the surrounding watershed (e.g. removing culturally-accelerated sediment, plugging surface drains, and filling pits within the wetlands) will help improve inundation frequency. Installing additional groundwaterpumping capabilities at public and WRP wetlands could potentially offset unfavorable conditions during years with low precipitation and limited inundated wetland area, thus making more food biomass available to waterfowl. Additional opportunities to increase natural inundation frequencies at wetlands within closed basin systems (e.g. playas) will require addressing hydrological modifications within the watersheds of the wetlands (Bishop and Vrtiska 2008). Regardless of temporal and spatial considerations, increasing inundation frequency of ephemeral wetlands in semi-arid regions will increase the probability that adequate wetland-derived energy is consistently available to spring-migrating waterfowl (RWBJV 2013; Nugent et al. 2015; Petrie et al. 2016).

Acknowledgements Primary funding for this project was provided by the Great Plains Landscape Conservation Cooperative, with additional funding provided by the Missouri Audubon Society, the Missouri Conservation Federation, and the Missouri Cooperative Fish and Wildlife Research Unit. The Rainwater Basin Wetland Management District of the United States Fish and Wildlife Service and the Nebraska Game and Parks Commission provided housing, vehicles, and access to management areas. The Missouri Cooperative Fish and Wildlife Research Unit is jointly sponsored by the MDC, the University of Missouri, the U.S. Fish and Wildlife Service, the U.S. Geological Survey, and the Wildlife Management Institute. Any use of trade, firm, or product names is for descriptive purposes only and does not imply endorsement by the U.S. Government. We gratefully acknowledge R. Askren, N. Hengst, B. Woodall, Z. Haverly, K. Anderson, A. Kaemmerer, A. Williams and C. Compagna for their assistance with sample collection and processing. Special thanks to R. Stutheit for guidance in the RWB, R. Grosse for providing GIS data layers, and D. Corcoran for statistical assistance. Finally, we are indebted to the more than thirty private landowners who participated in this study by allowing us access to their wetlands.

Open Access This article is distributed under the terms of the Creative Commons Attribution 4.0 International License (http:// creativecommons.org/licenses/by/4.0/), which permits unrestricted use, distribution, and reproduction in any medium, provided you give appropriate credit to the original author(s) and the source, provide a link to the Creative Commons license, and indicate if changes were made. 


\section{References}

Afton AD, Anderson MG (2001) Declining scaup populations: a retrospective analysis of long-term population and harvest survey data. Journal of Wildlife Management 65:781-796

Anderson JT, Smith LM (1998) Protein and energy production in playas: implications for migratory bird management. Wetlands 18(3):437-446

Ankney CD, Alisauskas RT (1991) Nutrient-reserve dynamics and diet of breeding female gadwalls. The Condor 93:799-810

Anteau MJ, Afton AD (2009) Lipid reserves of lesser scaup (Aythya affinis) migrating across a large landscape are consistent with the "spring condition" hypothesis. Auk 126(3):873-883

Baldassarre GA, Whyte RJ, Quinlan EE, Bolen EG (1983) Dynamics and quality of waste corn available to postbreeding waterfowl in Texas. Wildlife Society Bulletin 11(1):25-31

Ballard BM, Thompson JE, Petrie MJ, Checkett JM, Hewitt DG (2004) Diet and nutrition of northern pintails wintering along the southern coast of Texas. Journal of Wildlife Management 68(2):371-382

Barney ES (2008) Change in availability and nutritional quality of postharvest waste corn on waterfowl staging areas near long point. Thesis, University of Western Ontario, London, Canada, Ontario

Behney AC, O'Shaughnessy R, Eichholz MW, Stafford JD (2014) Influence of item distribution pattern and abundance of efficiency of benthic core sampling. Wetlands 34(6):1109-1121

Benke AC, Huryn AD (2006) Secondary production of macroinvertebrates. Methods in stream ecology 2:691-710

Benke AC, Huryn AD, Smock LA, Wallace JB (1999) Length-mass relationships for freshwater macroinvertebrates in North America with particular reference to the southeastern United States. Journal of the North American Benthological Society 18:308-343

Bishop AA, Vrtiska M (2008) Effects of the Wetlands Reserve Program on waterfowl carrying capacity in the Rainwater Basin region of South-Central Nebraska. U.S. Fish and Wildlife Service, Grand Island

Bishop AA, Grosse R, LaGrange T, Nugent E, Vogel A (2016) Summary of habitat distribution and abundance throughout the Rainwater Basin wetland complex 2004-2015. U.S. Fish and Wildlife Service, Grand Island

Bolen EG, Smith LM, Schramm HL Jr (1989) Playa lakes: prairie wetlands of the southern High Plains. BioScience 39(9):615-623

Bowyer MW, Stafford JD, Yetter AP, Hine CS, Horath MM, Havera SP (2005) Moist-soil plant seed production for waterfowl at Chautauqua National Wildlife Refuge, Illinois. The American Midland Naturalist 154(2):331-341

Brasher ME, Steckel JD, Gates RJ (2007) Energetic carrying capacity of actively and passively managed wetlands for migrating ducks in Ohio. Journal of Wildlife Management 71(8):2532-2541

Cariveau, A. B., D. C. Pavlacky Jr, A. A. Bishop, and T. G. LaGrange. 2011. Effects of surrounding land use on playa inundation following intense rainfall. Wetlands 31.1:65-73

Casanova MT, Brock MA (2000) How do depth, duration and frequency of flooding influence the establishment of wetland plant communities? Plant Ecology 147(2):237-250

Casanova MT, Casanova AJ (2016) Current and future risks of cropping wetlands in Victoria: technical report. Department of Environment, Land, Water and Planning

Davis CA, Bidwell JR (2008) Response of aquatic invertebrates to vegetation management and agriculture. Wetlands 28(3):793-805

Devries JH, Brook RW, Howerter DW, Anderson MG (2008) Effects of spring body condition and age on reproduction in mallards (Anas platyrhynchos). Auk 125(3):618-628
Dinno A (2015) Nonparametric pairwise multiple comparisons in independent groups using Dunn's test. Stata Journal 15:292-300

Drahota J, Reichart L (2015) Wetland seed availability for waterfowl in annual and perennial emergent plant communities of the Rainwater Basin. Wetlands 35(6):1105-1116

Duffy WG, LaBar DJ (1994) Aquatic invertebrate production in southeastern USA wetlands during winter and spring. Wetlands 14(2):8897

Dugger BD, Moore ML, Finger RS, Petrie MJ (2007) True metabolizable energy for seeds of common moist-soil plant species. Journal of Wildlife Management 71(6):1964-1967

Euliss NH, Harris SW (1987) Feeding ecology of northern pintails and green-winged teal wintering in California. Journal of Wildlife Management 51:724-732

Evans-Peters GR, Dugger BD, Petrie MJ (2012) Plant community composition and waterfowl food production on wetlands reserve program easements compared to those on managed public lands in western Oregon and Washington. Wetlands 32(2):391-399

Foster MA, Gray MJ, Kaminski RM (2010) Agricultural seed biomass for migrating and wintering waterfowl in the southeastern United States. Journal of Wildlife Management 74(3):489-495

Fox J, Weisberg S, Adler D, Bates D, Baud-Bovy G, Ellison S, and Firth D. (2016). Package car. https://r-forge.r-project.org/projects/car/

Fredrickson LH (1991) Strategies for Water Level Manipulations in Moist-soil Systems. U.S. Fish and Wildlife Service, Fish and Wildlife Leaflet 13.4.6, Washington, D.C.

Fredrickson LH, Taylor TS (1982) Management of seasonally flooded impoundments for wildlife. U.S. Fish and Wildlife Service Resource Publication 148. U.S. Fish and Wildlife Service, Washington, D.C.

Gray MJ, Smith LM, Brenes R (2004) Effects of agricultural cultivation on demographics of southern High Plains amphibians. Conservation Biology 18(5):1368-1377

Greer AK, Dugger BD, Graber DA, Petrie MJ (2007) The effects of seasonal flooding on seed availability for spring migrating waterfowl. The Journal of Wildlife Management 71(5):1561-1566

Hagy HM, Kaminski RM (2012) Apparent seed use by ducks in moistsoil wetlands the Mississippi Alluvial Valley. Journal of Wildlife Management 76:1053-1061

Hagy HM, Kaminski RM (2015) Determination of foraging thresholds and effects of application on energetic carrying capacity for waterfowl. PLoS One 10(3):e0118349

Hagy HM, Straub JN, Kaminski RM (2011) Estimation and correction of seed recovery bias from moist soil cores. Journal of Wildlife Management 75(4):959-966

Hagy HM, Stafford JD, Smith RV, Yetter AP, Hine CS, Horath MM, Whelan CJ (2017) Opportunity costs influence food selection and giving-up density of dabbling ducks. Journal of Avian Biology 48(6):804-814

Haukos DA, Smith LM (1993) Moist-soil management of playa lakes for migrating and wintering ducks. Wildlife Society Bulletin 21(3):288 298

Heitmeyer, ME, and Fredrickson LH. 1981. Do wetland conditions in the Mississippi delta hardwoods influence mallard recruitment? Transactions of the North American Wildlife and Natural Resources Conferences 46:44-57

Hitchcock, A. N. (2008) Diets of spring-migrating waterfowl in the Upper Mississippi River and Great Lakes Region. Thesis, Southern Illinois University-Carbondale, Carbondale, USA. Johnston

Hohman WL, Taylor TS, Weller MW (1988) Annual body weight change in ring- necked ducks (Aythya collaris). In: Weller MW (ed) Waterfowl in winter. University Minnesota Press, Minneapolis, pp $257-269$ 
Houlahan JE, Findlay CS (2004) Effect of invasive plant species on temperate wetland plant diversity. Conservation Biology 18(4): $1132-1138$

Johnson, AM (2007) Food abundance and energetic carrying capacity for wintering waterfowl in the Great Salt Lake wetlands. Thesis, Oregon State University, Corvallis

Kaminski RM, Prince HH (1981) Dabbling duck and aquatic macroinvertebrate responses to manipulated wetland habitat. Journal of Wildlife Management 45(1):15

Kaminski RM, Davis JB, Essig HW, Gerard PD, Reinecke KJ (2003) True metabolizable energy for wood ducks from acorns compared to other waterfowl foods. Journal of Wildlife Management 67:542-550

King SL, Twedt DJ, Wilson RR (2006) The role of the wetlands reserve program in conservation efforts in the Mississippi Alluvial Valley. The Wildlife Society Bulletin 34(4):914-920

Klemm DJ, Lewis PA, Fulk F, Lazorchak JM (1990) Macroinvertebrate field and laboratory methods for evaluating the biological integrity of surface waters. U.S. Environ- mental Protection Agency, Environmental Research Laboratory, Corvallis

Kross J, Kaminski RM, Reinecke KJ, Penny EJ, Pearse AT (2008) Moist-soil seed abundance in managed wetlands in the Mississippi Alluvial Valley. Journal of Wildlife Management 72(3):707-714

Kruskal WH, Wallis WA (1952) Use of ranks in one-criterion variance analysis. Journal of American Statistics 47(260):583-621

LaGrange TG (2005) Guide to Nebraska's wetlands and their conservation needs. Nebraska Game and Parks Commission, Lincoln

LaGrange TG, Dinsmore JJ (1989) Habitat use by mallards during spring migration through Central Iowa. Journal of Wildlife Management 53:1076-1081

Levene H (1960) Robust test for equality of variance, Contribution to Probability and Statistics, I. Olkin, SG Ghury, W. Hoeffding, WG Madow and HB Mann, eds. 275-292

Livolsi MC, Ringelman KM, Coluccy JM, Dibona MT, Williams CK (2015) Implications of uncertainty in true metabolizable energy estimates for estimating wintering waterfowl carrying capacities. Wildlife Society Bulletin 39(4):827-833

Loesch CR, Kaminski RM (1989) Winter body-weight patterns of female mallards fed agricultural seeds. Journal of Wildlife Management 53: 1080-1087

Marty JT (2005) Effects of cattle grazing on diversity in ephemeral wetlands. Conservation Biology 19(5):1626-1632

Meyer CK, Peterson SD, Whiles MR (2011) Quantitative assessment of yield, precision, and cost-effectiveness of three wetland invertebrate sampling techniques. Wetlands 31(1):101-112

Miller OD, Wilson JA, Ditchkoff SS, Lochmiller RL (2000) Consumption of agricultural and natural foods by waterfowl migrating through Central Oklahoma. Proceedings of the Oklahoma Academy of Sciences 80:25-31

Murkin HR, Kadlec JA (1986a) Responses by benthic macroinvertebrates to prolonged flooding of marsh habitat. Canadian Journal of Zoology 64(1):65-72

Murkin HR, Kadlec JA (1986b) Waterfowl and macroinvertebrate densities in a northern prairie marsh. Journal of Wildlife Management 50: 212-217

Murkin HR, Wrubleski DA, Reid F (1994) Sampling invertebrates in aquatic and terrestrial habitats. In: Bookhout TA (ed) Research and Management Techniques for Wildlife and Habitats. The Wildlife Society, Bethesda, pp 349-369
Natural Resources Conservation Service (2017a) Wetlands Reserve Program. https://wwwnrcsusdagov/wps/portal/nrcs/main/national/ programs/easements/acep/ Accessed 2017 March 2

Natural Resources Conservation Service (2017b) Agricultural conservation easement program. https:/wwwnrcsusdagov/wps/portal/nrcs/ main/national/programs/easements/acep/ Accessed 2017 March 2

Nelms CO, Twedt DJ (1996) Seed deterioration in flooded agriculture fields during winter. Wildlife Society Bulletin 24:85-88

North American Waterfowl Management Plan, Plan Committee (2012) North American Waterfowl Management Plan. People Conserving Waterfowl and Wetlands Canadian Wildlife Service, U.S. Fish and Wildlife Service, Secretaria de Medio Ambiente y Recursos Naturales

Nugent E, Bishop A, Grosse R, LaGrange T, Varner D, Vrtiska M (2015) An assessment of landscape carrying capacity for waterfowl and shorebirds in Nebraska's Rainwater Basin. A conservation effects assessment project wildlife component assessment report. Rainwater Basin Joint Venture, Wood River, p 45

Olmstead VG, Webb EB, Johnson RW (2013) Moist-soil seed biomass and species richness on wetlands reserve program easements in the Mississippi Alluvial Valley. Wetlands 33(2):1-10

Pearse AT, Krapu GL, Cox RR Jr, Davis BE (2011) Spring-migration ecology of northern pintails in south-Central Nebraska. Waterbirds 34(1):10-18

Petrie MJ, Fleskes JP, Wolder MA, Isola CR, Yarris GS, Skalos DA (2016) Potential effects of drought on carrying capacity for wintering waterfowl in the Central Valley of California. Journal of Fish and Wildlife Management 7(2):408-422

R Development Core Team (2017) R: a language and environment for statistical Computing. R Foundation for Statistical Computing, Vienna

Raines, RR, Gilbert MC, Gersib RA, Rosier WS, and Dinan KF (1990) Regulatory planning for Nebraska's Rainwater Basin wetlands. Prepared for the Rainwater Basin Advanced Identification Study. U.S. Environmental Protection Agency, Region VII, Kansas City, Kansas and U.S. Army Corps of Engineers, Omaha, Nebraska, USA

Rainwater Basin Joint Venture (RWBJV) (2013) The Rainwater Basin joint venture implementation plan. Rainwater Basin Joint Venture, Grand Island

Reed PB (1988) National list of plants that occur in wetlands: national summery. US Fish and Wildlife Service Biological Report 88(24)

Reinecke, K. J., R. M. Kaminski, D. J. Moorhead, J. D. Hodges, and J. R. Nassar. 1989. Mississippi Alluvial Valley. Pages 203-247 in L. M. Smith, R. L. Pederson, and R. M. Kaminski, editors. Habitat management for migrating and wintering waterfowl in North America. Texas Tech University Press, Lubbock

Riens JR, Schwarz MS, Mustafa F, Hoback WW (2013) Aquatic macroinvertebrate communities and water quality at buffered and non-buffered wetland sites on federal waterfowl production areas in the Rainwater Basin, Nebraska. Wetlands 33(6): $1025-1036$

Schepker, TJ (2017) Evaluating the Relationship between Local Food Availability and Wetland Landscape Structure in Determining Dabbling Duck Habitat use during Spring Migration. Thesis, University of Missouri

Schildman, G., and Hurt J (1984) Update of Rainwater Basin Wetland Survey. Survey of habitat work plan K-83. W-15-R-40. Nebraska Game and Parks Commission 
Sherfy MH (1999) Nutritional value and management of waterfowl and shorebird foods in Atlantic coastal moist-soil impoundments. Dissertation, Virginia Polytechnic Institute and State University, Blacksburg

Sherfy MH, Kirkpatrick RL, Richkus KD (2000) Benthos core sampling and chironomid vertical distribution: implications for assessing shorebird food availability. Wildlife Society Bulletin 28:124-130

Smith LM (2003) Playas of the Great Plains. University of Texas Press, Austin

Stafford JD, Kaminski RM, Reinecke KJ, Manley SW (2006) Waste rice for waterfowl in the Mississippi Alluvial Valley. Journal of Wildlife Management 70(1):61-69

Stafford, JD, Janke AK, Webb EB, and Chipps SJ (2016) Invertebrates in managed waterfowl marshes. Pages 565-600 in D. Batzer and D. Boix, editors, Invertebrates in Freshwater Wetlands: an international perspective on their ecology, Springer

Strader RW, and Stinson PH (2005) Moist-soil management guidelines for the U.S. Fish and Wildlife Service southeast region. <http:// www.fws.gov/columbiawildlife/Moist-SoilReport.pdf $>$. Accessed 20 Sep 2016

Straub, JN (2008) Energetic carrying capacity of habitats used by spring migrating waterfowl in the Upper Mississippi and Great Lakes Region during spring migration. Thesis, The Ohio State University, Columbus, USA

Straub JN, Gates RJ, Schultheis RD, Yerkes T, Coluccy JM, Stafford JD (2012) Wetland food resources for spring-migrating ducks in the upper Mississippi River and Great Lakes region. Journal of Wildlife Management 76(4):1-10

Stutheit RG, Gilbert MC, Whited PM, Lawrence KL (eds) (2004) A regional guidebook for applying the hydrogeomorphic approach to assessing wetland functions of Rainwater Basin depressional wetlands in Nebraska. ERDC/EL TR-04-4. U.S. Army Engineer Research and Development Center, Vicksburg
Swanson GA (1983) Benthic sampling for waterfowl foods in emergent vegetation. Journal of Wildlife Management 47(3):821-823

Swanson GA, Meyer MI, Adomaitis VA (1985) Foods consumed by breeding mallards on wetlands of south-Central North Dakota. Journal of Wildlife Management 49:197-203

Tapp, JL (2013) Waterbird use and food availability on Wetlands Reserve Program Easements enrolled in the Migratory Bird Habitat Initiative. M.Sc. thesis, University of Missouri, Columbia, USA

Tapp JL, Webb EB (2015) Aquatic invertebrate food base for waterbirds at wetland reserve program easements in the lower Mississippi Alluvial Valley. Wetlands 35(1):183-192

Tapp JL, Weegman MM, Webb EB, Kaminski RM, Davis JB (2017) Waterbird communities and seed biomass in managed and nonmanaged restored wetlands in the Mississippi Alluvial Valley. Restoration Ecology (In Print)

Tidwell PR, Webb EB, Vrtiska MP, Bishop AA (2013) Diets and food selection of female mallards and blue-winged teal during spring migration. Journal of Fish and Wildlife Management 4(1):63-74

Webb EB, Smith LM, Vrtiska MP, Lagrange TG (2010) Effects of local and landscape variables on wetland bird habitat use during migration through the rainwater basin. Journal of Wildlife Management 74(1): 109-119

Whiting DP, Whiles MR, Stone ML (2011) Patterns of macroinvertebrate production, trophic structure, and energy flow along a tallgrass prairie stream continuum. Limnologcial Oceanographer 56(3):887-898

Wilcoxon F (1945) Individual comparisons by ranking methods. Biometric Bulletin 1(6):80-83

Williams CK, Dugger BD, Brasher MG, Coluccy JM, Cramer DM, Eadie JM, Gray MJ, Hagy HM, Livolsi M, McWilliams SR, Petrie M, Soulliere GJ, Tirpak JM, Webb EB (2014) Estimating habitat carrying capacity for wintering waterfowl: considerations, pitfalls, and improvements. Proceedings of the north American duck symposium. Wildfowl Special Issue 4:407-435 